\title{
ANALISIS KESAPAN BELAJAR SISWA KELAS X MIPA DALAM PEMBELAJARAN KIMIA
}

\author{
Ahmad Ferdian $^{1}$, Siti Maryam², I Nyoman Selamat ${ }^{3}$ \\ 1,2,3 Universitas Pendidikan Ganesha \\ Singaraja, Indonesia \\ e-mail: ahmad.ferdian@undiksha.ac.id ${ }^{1}$, siti.maryam@undiksha.ac.id ${ }^{2}$, \\ nyoman.selamat@undiksha.ac.id ${ }^{3}$
}

\begin{abstract}
Abstrak
Penelitian ini bertujuan mendeskripsikan dan menjelaskan kesiapan belajar siswa kelas X MIPA ditinjau dari aspek kesiapan fisik, materiil, psikis, dan kognitif dalam pembelajaran kimia di SMA Negeri 4 Singaraja. Jenis penelitian ini adalah fenomenologi dengan menggunakan pendekatan deskriptif kualitatif. Subjek dalam penelitian ini adalah seluruh siswa kelas X MIPA SMA Negeri 4 Singaraja yang berjumlah 188 orang. Objek dalam penelitian ini adalah kesiapan belajar siswa yang ditinjau dari aspek kesiapan fisik, materiil, psikis, dan kognitif. Metode pengumpulan data pada penelitian ini di antaranya observasi, pemberian angket, pemberian pretest, dan wawancara. Data yang diperoleh dianalisis menggunakan teknik analisis deskriptif interpretatif. Hasil penelitian menunjukkan bahwa kesiapan belajar siswa kelas X MIPA SMA Negeri 4 Singaraja tahun ajaran 2018/2019 secara umum dalam kategori cukup, yang mana untuk kesiapan belajar siswa dari aspek kesiapan fisik dan materiil termasuk dalam kategori baik, kesiapan belajar siswa dari aspek kesiapan psikis termasuk dalam kategori cukup, dan kesiapan belajar dari aspek kognitif termasuk dalam kategori cukup.
\end{abstract}

Kata kunci: Kesiapan Belajar, Pembelajaran Kimia, SMA Negeri 4 Singaraja

\begin{abstract}
This research aims to describe and explain students' learning readiness of 10th grade mathematic and science in term of aspects physical, material, psychological, and cognitive readiness in learning chemistry at SMA Negeri 4 Singaraja. The type of research was phenomenology using a qualitative approach. The subjects in this reseach were all students' of 10th grade matematic and science SMA Negeri 4 Singaraja which amounted to 188 people. The object in this reseach was student learning readiness in term of aspects physical, material, psychological, and cognitive readiness. Data collection methods used were observation, questionnaire, giving pretest, and interviews. Data obtained were analyzed using interpretative descriptive technique. The results of this reseach show that the students' learning readiness of 10th grade mathematic and science SMA Negeri 4 Singaraja for academic year 2018/2019 in general is sufficient category, which for students' learning readiness from aspects of physical and material readiness was included in the good category, student readiness from aspects of psychological readiness included in sufficient
\end{abstract}


categories, and readiness to learn from cognitive aspects is included in the sufficient category.

Keywords: Chemistry Learning, Learning Readiness, SMA Negeri 4 Singaraja

\section{PENDAHULUAN}

Pembelajaran diartikan sebagai suatu proses interaksi peserta didik dengan pendidik dan sumber belajar pada satu lingkungan belajar berdasarkan Undang-Undang Sistem Pendidikan Nasional No 20 Tahun 2003. Pembelajaran dapat dikatakan berhasil apabila tercapainya tujuan pembelajaran. Terdapat beberapa faktor yang mempengaruhi keberhasilan proses pembelajaran salah satu faktor tersebut adalah kesiapan belajar siswa.

Kesiapan belajar merupakan suatu kondisi siswa yang dipersiapkan sebelum mengikuti proses pembelajaran di sekolah. Menurut Slameto (2010) kesiapan adalah keseluruhan kondisi seseorang yang membuatnya siap untuk memberikan respon atau jawaban dengan cara tertentu terhadap situasi tertentu. Kondisi tertentu yang dimaksud adalah kondisi fisik dan psikisnya. Kesiapan belajar perlu diperhatikan dalam proses pembelajaran karena proses pembelajaran yang disertai dengan adanya kesiapan belajar akan memudahkan siswa dalam memahami materi yang dipelajari. Selain itu, kesiapan belajar dapat mendorong siswa untuk memberikan respon positif dan berperan aktif dalam proses pembelajaran. Hal tersebut dipertegas oleh Wahyuni (2005) yang menyatakan bahwa kondisi siswa yang siap menerima pembelajaran dari guru, maka siswa akan berusaha merespon pertanyaan-pertanyaan yang diberikan oleh guru dan dengan adanya kesiapan belajar siswa akan termotivasi untuk mengoptimalkan hasil belajarnya.

Penerapan kurikulum 2013 menyebabkan pembelajaran harus berpusat pada siswa (student centered) sehingga siswa harus memiliki kesiapan belajar yang baik. Pembelajaran menggunakan pendekatan saintifik diharapkan mampu mengarahkan siswa lebih aktif dalam proses pembelajaran. Siswa dapat aktif selama proses pembelajaran apabila siswa memiliki kesiapan belajar yang baik sebelum mebgikuti proses pembelajaran. Kesiapan belajar yang baik dapat menjadikan proses pembelajaran berlangsung optimal dan sesuai tuntutan kurikulum 2013.

Pembelajaran kimia di beberapa sekolah selama ini terlihat kurang menarik. Siswa merasa bosan dalam mengikuti pembelajaran dan setelah dilakukan wawancara siswa kurang memiliki minat dalam pelajaran kimia sehingga dalam pembelajaran kondisi kelas menjadi kurang kondusif dan menyebabkan nilai kimia siswa dibawah kriteria ketuntasan minimal (KKM). Dalam proses pembelajaran siswa cenderung pasif didalam kelas dan kurang memperhatikan pelajaran, hanya beberapa siswa saja yang aktif bertanya kepada guru terkait materi yang belum dipahami. Hal tersebut dapat terjadi karena siswa tidak tau apa yang harus ditanyakan kepada guru ketika proses pembelajaran berlangsung yang salah satu penyebabnya adalah siswa tidak memiliki kesiapan belajar khususnya dalam pembelajaran kimia. Oleh karena itu, siswa perlu memiliki kesiapan belajar sebelum mengikuti pembelajaran kimia agar pembelajaran menjadi efektif, tujuan pembelajaran tercapai, dan siswa lebih aktif dalam proses pembelajaran sehingga siswa lebih mudah dalam memahami materi pembelajaran kimia yang diajarkan oleh guru di sekolah.

SMA Negeri 4 Singaraja telah menerapkan kurikulum 2013 dan menggunakan pendekatan scientific dalam pembelajaran kimia. Akan tetapi dalam penerapannya dalam proses pembelajaran khususnya pembelajaran kimia masih belum optimal. Siswa yang seharusnnya lebih aktif dalam proses pembelajaran justru siswa terlihat cenderung pasif dalam proses pembelajaran dan kurang memiliki kesiapan dalam mengikuti proses pembelajaran. Siswa tidak mengajukan pertanyaan saat pembelajaran dan beberapa siswa tidak bisa menjawab pertanyaan yang diberikan oleh guru. Dalam pembelajaran siswa tidak membawa buku paket pembelajan kimia hanya membawa buku cacatan saja. Buku catatan yang dibawa tidak dipergunakan oleh beberapa siswa untuk mencatat materi pembelajaran. Hal ini dapat terlihat dari hasil observasi yang telah dilakukan khususnya pada kelas X MIPA SMA Negeri 4 Singaraja. 
Tabel 1. Penilaian Hasil Pretest skala lima

\begin{tabular}{lcc}
\hline & Interval tingkat & Kriteria \\
& penguasaan & \\
\hline $85 \%-100 \%$ & & Baik sekali \\
$75 \%-84 \%$ & Baik \\
$60 \%-74 \%$ & Cukup \\
$40 \%-59 \%$ & Kurang \\
$0 \%-39 \%$ & Sangat kurang \\
\hline
\end{tabular}

Berdasarkan paparan tersebut diatas, perlu adanya gambaran lebih jelas terkait dengan kesiapan belajar siswa kelas X MIPA SMA Negeri 4 Singaraja. Sehingga perlu dilakukan penelitian lebih lanjut agar mengetahui kesiapan belajar siswa. Oleh karena itu, penelitian ini bertujuan untuk mendeskripsikan dan menjelaskan kesiapan belajar siswa yang ditinjau dari aspek kesiapan fisik, materiil, psikis, dan kognitif siswa kelas x MIPA SMA Negeri 4 Singaraja dalam pembelajaran kimia.

\section{METODE}

Penelitian ini menggunakan pendekatan deskriptif kualitatif dengan jenis penelitian fenomenologi. Penelitian ini dikategorikan sebagai penelitian deskriptif dikarenakan suatu fenomena atau peristiwa dideskripsikan secara sistematis sesuai dengan apa adanya (Dantes, 2012). Penelitian deskriptif dilakukan untuk memperoleh informasi mengenai keadaan saat ini. Jenis penelitian ini adalah penelitian fenomenologi. Hal tersebut dikarenakan penelitian ini berorientasi untuk memahami, menggali, menafsirkan arti dari peristiwa, dan hubungannya dengan orang-orang yang biasa dalam situasi tertentu.

Penelitian ini dilaksanakan di SMA Negeri 4 Singaraja yang beralamat di Jalan Melati, kelurahan Banjar Jawa, Singaraja, Bali. Penelitian ini dilaksanakan pada semester genap tahun ajaran 2018/2019. Objek dalam penelitian ini adalah seluruh siswa kelas X MIPA SMA Negeri 4 Singaraja. Subjek dalam penelitian ini adalah kesiapan belajar siswa yang ditinjau dari aspek kesiapan fisik, materiil, sikis, dan kognitif. Pengumpulan data dilakukan dengan metode observasi, penyebaran angket, pemberian pretest, dan wawancara.

\section{HASIL DAN PEMBAHASAN}

Hasil penelitian yang diperoleh berdasarkan hasil observasi, angket, pretest,dan wawancara terkait kesiapan belajar siswa kelas X MIPA SMA Negeri 4 Singaraja. Kesiapan belajar tersebut ditinjau dari aspek kesiapan fisik, materiil, psikis, dan kognitif.

Berdasarkan data yang disajikan pada Tabel 3, kesiapan belajar siswa yang dilihat dari empat aspek kesiapan belajar didapatkan hasil $72,78 \%$ termasuk dalam kategori cukup berdasarkan kategori kesiapan belajar yang dikemukakan oleh Rohani (2004). Masing-masing aspek kesiapan dijelaskan sebagai berikut.

\section{Kesiapan Fisik}

Kesiapan belajar siswa kelas X MIPA SMA Negeri 4 Singaraja tahun ajaran 2018/2019 dilihat dari aspek kesiapan fisik dalam mengikuti pembelajaran kimia yang diperoleh dari hasil angket pada Tabel 3 termasuk dalam kategori baik. Untuk memperlihatkan kesiapan fisik yang dimiliki oleh siswa tidak hanya menggunakan metode angket tetapi juga menggunakan metode observasi dan wawancara mendalam terhadap siswa kelas X MIPA. Kesiapan fisik siswa dilihat dari tiga indikator saat pembelajaran kimia berlangsung yaitu kondisi kesehatan fisik siswa, mengantuk, dan kelehan saat pembelajaran kimia.

Temuan hasil observasi yang diperoleh yaitu saat pembelajaran berlangsung pada jam pelajaran ke 1 sampai ke 5 (07.15-11.45 WITA) siswa dalam kadaan fisik yang baik artinya siswa tidak merasa kelelahan dan mengantuk selama pembelajaran berlangsung. Akan tetapi saat pembelajaran pada jam ke 5 sampai jam 10 (11.45 - 15.30 WITA) siswa sudah mulai merasa kelelahan saat proses pembelajaran dan beberapa siswa mengantuk saat pembelajaran. Akan tetapi hal tersebut tidak mempengaruhi secara signifikan pembelajaran kimia yang berlangsung. Hal tersebut juga diperoleh dari hasil wawancara dengan beberapa siswa.

Selain dari faktor kelelahan dan mengantuk, kondisi kesehatan fisik siswa juga berperan sangat penting dalam keberhasilan pembelajaran kimia. dari hasil angket yang sebagian besar 
siswa dalam kondisi kesehatan fisik yang baik. Kondisi penglihatan maupun pendengaran dalam kondisi yang baik. Hal tersebut juga sesuai dengan hasil wawancara langsung yang telah dilakukan kepada beberapa siswa.

Kesiapan belajar khususnya dilihat dari aspek kesiapan fisik sangat berperan penting dalam pembelajaran kimia. Kesiapan dalah keseluruhan kondisi individu yang membuatnya siap untuk memberikan respon atau jawaban di dalam cara tertentu terhadap situasi tertentu. Kondisi tertentu yang dimaksud salah satunya adalah kondisi fisik, sehingga untuk mencapai tingkat kesiapan yang maksimal diperlukan kondisi fisik yang dapat menunjang kesiapan siswa dalam proses pembelajaran. Kesiapan sebagai seorang siswa dalam belajar akan menentukan kualitas proses dan hasil belajar siswa tersebut. Apabila kondisi fisik siswa baik maka besar kemungkinan hasil belajar yang diperoleh juga baik (Slameto, 2010).

Kesiapan diri siswa sangat berperan penting dalam mencapai keberhasilan pembelajaran. Keberhasilan siswa melakukan kesiapan sebelum mengikuti pelajaran dapat menentukan berhasil tidaknya suatu pembelajaran tergantung kepada bagaimana proses belajar yang dialami oleh siswa. Sebagaimana yang dikemukakan Djamarah (2002) bahwa kesiapan fisik berkaitan dengan kesehatan yang akan berpengaruh pada hasil belajar dan penyesuaian social individu. Kesiapan fisik yang baik akan membantu siswa dalam mengikuti pembelajaran. Kondisi fisik yang baik akan menyebabkan siswa bersemangat dalam belajar sehingga siswa menjadi lebih aktif dalam pembelajaran dan mudah menyerap pelajaran yang disampaikan oleh guru.

Berdasarkan hasil angket, observasi, dan wawancara yang telah diuraikan di atas maka dapat disimpulkan secara keseluruhan kondisi kesiapan belajar siswa kelas X MIPA SMA Negeri 4 Singaraja tahun ajaran 2018/2019 dilihat dari aspek kesiapan fisik termasuk dalam kategori kesiapan yang baik. Berdasarkan hasil temuan tidak terdapat masalah yang cukup berarti terkait kesiapan fisik siswa. Siswa secara fisik sudah siap untuk mengikuti dan menerima pembelajaran kimia di sekolah.

\section{Kesiapan Materiil}

Kesiapan belajar siswa kelas X MIPA SMA Negeri 4 Singaraja tahun ajaran 2018/2019 dilihat dari aspek kesiapan materiil dalam mengikuti pembelajaran kimia yang diperoleh dari hasil angket termasuk dalam kategori baik. Kesiapan materiil siswa dilihat dari beberapa indikator diantaranya kelengkapan alat tulis, buku catatan, buku paket kimia, dan Lembar Kerja Siswa (LKS). Kelengkapan tersebut dijadikan sebagai acuan dalam menilai kesiapan belajar siswa khususnya pada aspek kesiapan materiil. Kesiapan belajar dari aspek kesiapan materiil diperoleh dari hasil observasi, angket, dan wawancara terhadap siswa kelas X MIPA.

Berdasarkan hasil observai dan wawancara yang telah dilakukan diketahui bahwa siswa membawa kelengkapan pembelajaran kimia dengan lengkap sebagai penunjang pembelajaran kimia di sekolah diantaranya buku tulis untuk catatan, alat tulis, dan LKS kimia sedangkan buku paket kimia hanya beberapa siswa saja yang membawanya padahal buku paket kimia diberikan kepada setiap siswa sebagai penunjang pembelajaran kimia. Akan tetapi dalam pembelajaran guru hanya mengandalkan LKS untuk pembelajaran dan jarang menggunakan buku paket kimia sehingga menyebabkan siswamalas untuk membawa buku paket saat pembelajaran. Padahal berdasarkan Permendiknas Nomor 11 Tahun 2005menyatakan bahwa buku paket pembelajaran wajib digunakan dan sangat berperan penting untuk menunjang proses pembelajaran di sekolah. Sehingga guru dituntut untuk menggunakan buku paket dalam pembelajaran kimia dan siswa wajib memiliki buku paket kimia dan menggunakan buku tersebut selama mengikuti pembelajaran kimia di sekolah. Lembar Kerja Siswa (LKS) juga memiliki fungsi yang penting untuk mempermudah proses pembelajaran dan penuntun siswa dalam belajar. LKS berisi ringkasan materi kimia dan soal-soal latihan sehingga memudahkan siswa dalam belajar

Buku catatan merupakan salah satu kelengkapan yang mendukung kesiapan belajar siswa menjadi lebih optimal. Banyak atau sedikitnya materi yang mampu ditangkap oleh siswa berkaitan juga dengan daya ingat yang dimiliki setiap siswa. Menurut Sprenger (2011) daya ingat dapat dikembangkan dengan tujuh langkah pengajaran, yaitu: (1) reach atau menjangkau; (2) reflect atau merefleksikan; (3) recode atau mengodekan ulang; (4) reinforce atau menguatkan; (5) rehearse atau berlatih; (6) review atau menguji kembali; dan (7) retrieve atau pemanggilan kembali. Dari ketujuh cara untuk mengembangkan daya ingat tersebut, buku catatan berperan penting khususnya pada proses recode dan review. Siswa dapat merekam/mencatat materi pelajaran yang penting dan susah di hafalkan. Jadi ketika siswa lupa, mereka dapat membuka kembali (review) buku catatannya untuk mengembalikan ingatannya tentang suatu materi pelajaran. Sehingga buku catatan dan alat tulis berperan penting dalam menunjang terjadinya pembelajaran yang optimal. 
Oleh karena itu, buku catatan dan alat tulis menjadi alat pendukung pembelajaran yang harus dipersiapkan siswa sebelum mengikuti pembelajaran.

Berdasarkan hasil dari angket, observasi, dan juga wawancara yang telah diuraikan di atas maka dapat disimpulkan secara keseluruhan kondisi kesiapan belajar siswa kelas X MIPA SMA Negeri 4 Singaraja tahun ajaran 2018/2019 dilihat dari aspek kesiapan materiil termasuk dalam kategori kesiapan yang baik. Siswa sudah mempersiapkan kelengkapan pendukung proses pembelajara kimia diantaranya buku catatan, alat tulis, dan LKS. Akan tetapi dari segi kelengkapan masih perlu ditingkatkan khususnnya dalam penggunaan buku paket kimia dalam pembelajaran sehingga proses pembelajaran bisa lebih optimal.

\section{Kesiapan Psikis}

Kesiapan belajar siswa kelas X MIPA SMA Negeri 4 Singaraja tahun ajaran 2018/2019 dilihat dari aspek kesiapan psikis dalam mengikuti pembelajaran kimia diperoleh dengan menggunakan metode angket dan wawancara. Kesiapan psikis siswa dilihat dari beberapa indikator diantaranya konsentrasi selama proses pembelajaran, motivasi dalam mempelajari kimia, dan kondisi mental dan emosional siswa. Kesiapan psikis siswa dari data hasil angket didapatkan hasil kesiapan psikis siswa termasuk dalam kategori kesiapan cukup. Untuk menginterpretasi kesiapan belajar siswa dari aspek kesiapan psikis tidak hanya dengan menggunakan angket tetapi juga melalui wawancara agar diketahui hasil yang lebih akurat.

Berdasarkan hasil wawancara diketahui konsentrasi siswa selama embelajaran termasuk dalam kategori cukup. Konsentrasi siswa dipengaruhi beberapa faktor diantaranya kondisi kelas saat pembelajaran kimia berlangsung, jam pelajaran kimia dan tingkat kesulitan materi. Apabila kondisi kelas saat pembelajaran kondusif siswa mampu berkonsentrasi dengan baik selama pembelajaran kimia berlangsung. Dilihat dari segi minat belajar siswa tergolong dalam kategori cukup.

Minat belajar bengaruhnya terhadap hasil belajar sebab dengan memiliki minat, seseorang akan dengan senang hati melakukan sesuatu yang diminatinya. Sebaliknya tanpa minat, seseorang tidak mungkin melakukan sesuatu. Seperti yang diungkapkan oleh James (dalam Usman, 2003) bahwa minat siswa merupakan faktor utama yang menentukan derajat keaktifan belajar siswa. Disinilah peran guru yang harus bisa mengarahkan siswa dan memberikan pemahaman mengapa mereka harus belajar kimia. Minat siswa untuk belajar kimia perlu digali lebih dalam lagi karena ini penting untuk mencapai tujuan yang diharapkan dari pembelajaran kimia. Hal ini dapat ditingkatkan salah satunya dengan membuat siswa merasa tertarik dan tidak jenuh untuk melakukan proses belajar. Permainan-permainan seperti games di kelas juga akan menarik rasa ingin tahu dan menimbulkan motivasi intrinsik dari dalam diri siswa (Djiwandono, 2006).

Kondisi kesiapan psikis siswa juga dilihat dari konsentrasi siswa dan kondisi mental dan emosional siswa. Siswa yang berkonsentrasi dengan baik selama pembelajaran maka siswa akan cepat memahami materi yang diajarkan dan siswa akan aktif dalam pembelajaran. Jika siswa siap secara psikis untuk mengikuti pembelajaran maka siswa tersebut akan memiliki hasrat atau motivasi untuk belajar, berkonsentrasi dangn baik selama pembelajaran, dan memperhatikan seluruh proses pembelajaran yang dilakukan (Djamarah, 2002). Hal tersebut sangatlah penting dan wajib dilakukan oleh setiap siswa jika siswa siap secara psikis untuk belajar maka proses pembelajaran menjadi lebih aktif dan berlangsung optimal, serta siswa akan lebih cepat mamahami materi yang dibelajarkan.

Kondisi mental dan emosional siswa juga berpengaruh terhadap kesusesan proses pembelajaran. Siswa yang kondisi mental dan emosionalnya baik maka akan lebih mudah memahami materi dan lebih menghargai proses pembelajarn yang dilakukan guru di sekolah. Jika kondisi psikologis siswa kurang baik misalnnya gelisah, tertekan, dan mudah marah hal tersebut tidak akan menguntungkan bagi kelancaran proses pembelajaran. Sehingga atas dasar tersebut maka siswa wajib mempersiapkan disi secara psikis sebelum mengikuti pembelajaran kimia di sekolah.

Berdasarkan hasil dari angket dan wawancara, dan observasi yang telah diuraikan di atas maka dapat disimpulkan secara keseluruhan kondisi kesiapan belajar siswa kelas X MIPA SMA Negeri 4 Singaraja tahun ajaran 2018/2019 dilihat dari aspek kesiapan psikis termasuk dalam kategori kesiapan yang cukup. Dari segi mental dan emosional siswa sudah siap untuk belajar akan tetapi siswa kurang memiliki motivasi dalam pembelajaran kimia sehingga sehingga siswa tidak merasa pembelajan kimia penting bagi mereka. Oleh karena itu, motivasi dalam belajar kimia siswa kelas X MIPA SMA Negeri 4 Singaraja perlu ditingkatkan sehingga siswa benar-benar sisap secara psikis untuk mengikuti pembelajaran kimia. 


\section{Kesiapan Kognitif}

Kesiapan belajar siswa kelas X MIPA SMA Negeri 4 Singaraja tahun ajaran 2018/2019

dilihat dari aspek kesiapan kognitif dalam mengikuti pembelajaran kimia diteliti menggunakan

metode tes, angket, dan wawancara. Hasil yang diperoleh dari pemberian angket kepada siswa menunjukkan kesiapan kognitif yang dimiliki siswa berada pada kategori cukup. Untuk menilai kesiapan belajar siswa dari segi kesiapan kognitif tidak hanya didasarkan pada hasil angket tetapi juga menggunakan data pendukung dari hasil pretest dan wawancara sehingga dihasilkan hasil yang lebih akurat. Kesiapan kognitif siswa dilihat dari beberapa indikator diantaranya aktivitas siswa sebelum pembelajaran kimia dimulai (belajar mandiri, berkelompok, membaca materi pelajaran, dan membuat ringkasan pelajaran), aktivitas siswa selama pembelajaran kimia (aktif bertanya, dan menjawab pertanyaan), dan dari hasil pretest sebelum pembelajaran kimia dimulai.

Hasil yang diperoleh dipastikan dengan pemberian pretest sebelum pembelajaran kimia dimulai untuk memperkuat temuan yang diperoleh Pemberian pretest bertujuan untuk mengetahui apakah siswa mempelajari materi kimia sebelum diberikan di sekolah atau tidak. Hasil pretest inilah dapat dijadikan sebagai salah satu acuan untuk menginterpretasi apakah siswa mempersiapkan dirinya untuk belajar materi kimia dirumah baik secara mandiri maupun berkelompok atau tidak.

Hasil angket dan pretest tersebut kemudian diperkuat dengan wawancara sehingga didapatkan hasil yang lebih akurat. Berdasarkan hasil wawancara yang telah dilakukan diketahui siswa kurang mempersiapkan diri sebelum pembelajaran kimia. Sebagian besar siswa tidak mempelajari materi kimia sebelum materi tersebut dipelajari di sekolah. Hal tersebut yang menyebabkan nilai pretest siswa sangat rendah.

Salah satu tujuan belajar adalah pencapaian hasil belajar yang meliputi ranah kognitif (mencakup pengetahuan dan fakta), afektif (mencakup sikap), psikomotorik (mencakup keterampilan bertindak). Dari ketiga ranah tersebut, ranah kognitif merupakan ranah yang paling mendominasi dan menonjol karena berhubungan dengan kemampuan siswa dalam menguasai materi pelajaran, serta sering dijadikan sebagai tolok ukur keberhasilan siswa (Sudjana, 2010). Intelegensi (pengetahuan) merupakan faktor yang berperan penting dalam menentukan hasil belajar. Seseorang yang mempunyai intelegensi tinggi umumnya mudah belajar dan hasilnya cenderung baik (Sulaeman, 2008). Hal yang dapat dilakukan siswa untuk dapat memiliki intelegensi yang tinggi salah satunya adalah belajar. Belajar yang dilakukan secara berkelanjutan akan membuat siswa lebih siap menerima pelajaran.

Pemberian pretest sangatlah berpengaruh terhadap kesiapan belajar siswa. Dengan diberikannya pretest maka siswa akan berupaya untuk belajar seblumnya sehingga hal ini akan memaksa siswa untuk belajar. Sebelum mengikuti proses pembelajaran kimia di sekolah hendaknya siswa memiliki pengetahuan awal agar ketiaka belajar di sekolah proses asimilasi dan akomodasi akan terjadi sehingga siswa lebih mudah memahami pelajaran yang diberikan. Hal tersebut sesuai dengan hasil penelitian Jayadiningrat et all (2017) yang memperoleh hasil penelitian bahwa pemberian kuis sebelum pembelajaran kimia dapat meningkatkan kesiapan belajar siswa dan meningkatkan pemahaman siswa dalam mempelajari kimia. oleh sebab itu, kesiapan kognitif sangatlah penting dimiliki oleh siswa untuk keberhasilan proses pembalajaran.

Berdasarkan hasil dari angket, pretest, wawancara, dan observasi yang telah diuraikan di atas maka dapat disimpulkan secara keseluruhan kondisi kesiapan belajar siswa kelas X MIPA SMA Negeri 4 Singaraja tahun ajaran 2018/2019 dilihat dari aspek kesiapan kognitif termasuk dalam kategori kesiapan yang cukup tetapi masih perlu ditingkatkan khususnnya darisegi perseiapan siswa sebelum mengikuti pembelajaran kimia disekolah dengan cara mempelajari materi, membaca materi, dan membuat catatan terkait materi kimia yang akan dipelajari. Sehingga pembelajaran dapat berjalan dengan optimal.

\section{SIMPULAN DAN SARAN}

Berdasarkan hasil pembahasan yang telah diuraikan maka dapat disimpulkan bahwa kesiapan belajar siswa kelas X MIPA SMA Negeri 4 Singaraja dalam mengikuti pembelajaran kimia secara umum termasuk kesiapan yang cukup. Kesiapan tersebut ditinjau dari empat aspek kesiapan belajar. Kesiapan fisik dan kesiapan materiil termasuk dalam kategori kesiapan yang baik, kesiapan psiskis termasuk dalam kategori cukup, dan kesiapan kognitif termasuk dalam kategori kurang. Kesiapan belajar dari segi kesiapan kognitif yaitu kesiapan dari segi materi pembelajaran sebelum pembelajaran dilakukan di sekolah dan kesiapan psikis yaitu dari minat 
belajar siswa perlu ditingkatkan, guna terciptanya proses pembelajaran yang baik sehingga dapat menunjang hasil belajar kimia yang maksimal.

DAFTAR RUJUKAN

Ahmad, S. 2014. Probelmatika Kurikulum 2013 dan kepemimpinan Instruksional Kepala Sekolah. Jurnal Pencerahan. 8 (2) 98-107.

Aries, E, F. 2011. Asesmen dan Evaluasi. Yogyakarta: Aditya Media Publishing.

Arikunto, S. 2013. Metodologi Penelitian Suatu Pendekatan Proposal. Jakarta: PT Rineka Cipta

2006. Prosedur Penelitian pendekatan Praktek. Jakarta: PT rineka Cipta

Dantes, N. 2012. Metode Penelitian Pendidikan. Yogyakarta: CV Andi Offset.

Darso. 2011. Kesiapan Belajar Siswa dan Interaksi Belajar Mengajar terhadap Prestasi Belajar. Jurnal Invotec. 2 (2) 145-160.

Djamarah, S. 2002. Prestasi Belajar dan Kompetensi Guru. Jakarta: Usaha Nasional. 2002. Rahasia Sukses Belajar. Jakarta: Usaha Nasional.

Djiwandono, S, E, W. 2006. Psikologi Pendidikan. Jakarta: Grasindo.

Effendi. 2017. Hubungan Readiness (kesiapan) Belajar Siswa dengan Hasil Beljar Fisika Siswa Kelas X SMK Muhammadiyah 03 Sukaraja. Jurnal Pendidikan Fisika, 5 (1) 15-24.

Jayadiningrat, M, G, Tika, I, N, Yuliani, N, P. 2017. Meningkatkan Kesiapan dan Hasil Belajar Siswa pada Pembelajaran Kimia dengan Pemberian Kuis di Awal Pembelajaran. Jurnal Pendidikan Kimia Indonesia. 1 (1) 8-12.

Peraturan Menteri Pendidikan Nasional Nomor 11 Tahun 2005 Tentang Buku Teks Pembelajaran. Jakarta

Riduwan. 2011. Skala Pengukuran Variabel-Variabel Penelitian. Bandung: Alfabeta.

Mudjiyono, 2009. Belajar dan Pembelajaran. Jakarta: PT. Rineka Cipta. 2013. Metode dan Teknik Menyusun Tesis. Bandung: Alfabeta.

Rohani, A. 2004. Pengelolaan Pengajaran. Jakarta: Rineka Cipta.

Sari, S, N. 2014. Aalisis kesiapan belajar Siswa dalam Mengikuti Proses Pembelajaran Biologi Kelas X di beberapa SMA Negeri Kota Jambi. Artikel IImiah. FKIP Universitas Jambi.

Slameto. 2010. Belajar dan Faktor-faktor yang Mempengaruhinya. Jakarta: Rineka Cipta.

Sprenger, M. 2011. Cara Mengajar agar Siswa Tetap Ingat. Jakarta: Erlangga.

Sugiyono. 2009. Metode Penelitian Kuantitatif kualitatif dan R\&D. Bandung: Alfabeta.

Wahyuni, D. 2005. Pengaruh Kesiapan Belajar, Motivasi belajar dan Pengulangan Materi Pelajaran terhadap Hasil Belajar Mata Pelajaran Ekonomi Pada Siswa Kelas 11 MA Al Asror Gunung Pati Tahun Pelajaran 2004/2005. Skripsi. Semarang: UNS. 